themselves there was no let up until early November when other major political events took over the front pages. The first attempter's initial plans for a mock self-immolation had gone awry (Kalra, 1990). It would appear that this attempt was an outlet for suppressed frustration and anger where the perpetrator chose the easiest and the most dramatic course of action to resolve his problems of identity by making a bid for glorious freedom (Kumar, 1990). Some of the subsequent suicides may have been purely for personal reasons but the media coverage and the political context may have offered them a way out by sanctification.

Durkheim, E. (1952) Suicide (transl. Simpson). London: Routledge \& Kegan Paul.

KALRA, M. (1990) Act of desperation. India Today, 15 October, 27.

KumAR, R. S. (1990) Like wild fire. Times of India Sunday Review', 21 October, 2.

RaO, A. V., Mahendran, N., Gopalakrishnan, C. et al (1989) One hundred female burns cases: a study in sociology. Indian Journal of Psychiatry, 31, 43-50.

Institute of Psychiatry

DiNeSh BHUGRA

London SE5 8AF

\section{NMS and genetic drug oxidation}

SIR: Our recent paper (Otani et al, Journal, June $1991,158,850-853$ ) of the familial occurrence of NMS suggests that the predisposition to this syndrome may be related to a genetic factor. Meanwhile, the genetically determined oxidation polymorphism is involved in the metabolism of haloperidol (Gram et al, 1989) and perphenazine (Dahl-Puustinen et al, 1989) is related to the debrisoquine/sparteine/ metoprolol-type polymorphism, whereas that of diazepam is dependent on the mephenytoin polymorphism (Bertilsson et al, 1989). Therefore, we studied whether patients developing NMS would show an impaired drug oxidation capacity (i.e. poor metaboliser status).

The subjects were five patients with NMS. Patient 1 was the mother, and patient 2 was the elder daughter described in our recent report. Patient 3 (68-year-old female), patient 4 (20-year-old female), and patient 5 (63-year-old male) were unrelated by lineage and birth. Patients 1, 3 and 4 developed two episodes. At the onset of the first episode of patient 3, serum haloperidol level was $16 \mathrm{ng} / \mathrm{ml}$ (daily dose $10 \mathrm{mg}$ ), and at the second episode of patient 4 , serum zotepine level was $9 \mathrm{ng} / \mathrm{ml}$ (daily dose $40 \mathrm{mg}$ ). The assessment of oxidation capacity (i.e., phenotyping test) by metoprolol tartrate $(100 \mathrm{mg})$ and racemic mephenytoin $(100 \mathrm{mg})$, which are metabolised by two independently different P-450 isozymes (Horai et al, 1989), was conducted after recovery from NMS, with their consent. At the time of the phenotyping test, all but patient 2 were taking one or two benzodiazepines such as alprazolam, diazepam, flunitrazepam, and nitrazepam, and patient 1 was also taking zotepine. The phenotyping procedure was similar to that in our previous study (Horai et al, 1989), except that the two test drugs were administered simultaneously. Oxidation capacities of metoprolol and mephenytoin were expressed by the $\log _{10}$ urinary metoprolol/a-hydroxymetoprolol ratio $\left(\log _{10}\right.$ metabolic ratio (MR)) and the $\log _{10}$ percentage of urinary excretion of 4-hydroxymephenytoin per the dose administered as racemate mephenytoin $\left(\log _{10} 4-\mathrm{HM} \%\right.$ of dose), respectively. Their phenotyping test values $\left(\log _{10} \mathrm{MR}\right.$ and $\log _{10} 4-\mathrm{HM} \%$ of dose) were as follows: -0.240 and 1.26 in patient 1 , -0.323 and 1.21 in patient $2,-0.210$ and 1.04 in patient $3,-0.991$ and 1.20 in patient 4 , and 0.238 and 1.41 in patient 5 .

Contrary to our hypothetical expectation, all the cases showed a normal oxidation capacity (extensive metaboliser status) of both the test drugs according to the phenotyping criteria used in our previous Japanese population study (Horai et al, 1989). One may wonder if the phenotypic expression in four of the five cases might have been modified by the possible drug interactions, because they were taking a neuroleptic and/or benzodiazepines when phenotyped. However, if this were the case, the oxidation status should have changed from an extensive to poor metaboliser phenotype. Serum levels of neuroleptics measured at the onset of NMS were not toxic in the two patients; the haloperidol level in patient 3 was within the therapeutic window proposed by Santos et al (1989). The zotepine level in patient 4 was within the range similar to the previously reported 21 patients (i.e. $5-317 \mathrm{ng} / \mathrm{ml}$ ) without developing any significant side effects including NMS. Therefore, this report suggests that the development of NMS appears to be ascribable neither to a genetically determined impaired drug oxidation nor to a toxic neuroleptic level.

Bertilsson, L., Henthorn, T. K., SANZ, E., et al (1989) Importance of genetic factors in the regulation of diazepam metabolism: relationship to S-mephenytoin, but not debrisoquin, hydroxylation phenotype. Clinical Pharmacology \& Therapeutics, 45. 348-355.

Dahl-Puustinen, M-L., Lidén, A., Alm, C., et al (1989) Disposition of perphenazine is related to polymorphic debrisoquin hydroxylation in human being. Clinical Pharmacology \& Therapeutics, 46, 78-81. 
Gram, L. F., Debruyne, D., Caillard, V., et al (1989) Substantial rise in sparteine metabolic ratio during haloperidol treatment. British Journal of Clinical Pharmacology, 27, 272-275.

Hora, Y., Nakano, M., Ishizakı, T., et al (1989) Metoprolol and mephenytoin oxidation polymorphisms in far eastern oriental subjects: Japanese versus mainland Chinese. Clinical Pharmacology \& Therapeutics, 46, 198-207.

Santos, J. L., Cabranes, J. A., Almoguera, J., et al (1989) Clinical implications of determination of plasma haloperidol levels. Acta Psychiatrica Scandinavica, 79, 348-354.
Koichi Otani, Sunao Kaneko YUTAKa FUKUSHIMA

Department of Neuropsychiatry

Hirosaki University Hospital

Hirosaki, Japan

Clinical Research Institute

KaN Chiba, TaKashi Ishizaki

National Medical Center

Tokyo, Japan

\section{CORRIGENDUM}

Journal, May 1991, 158, 603 (column 1, under The ESF Programme on the Molecular Neurobiology of Mental Illness). The sentence beginning "Last year
..." should read: "Last year it agreed to contribute $£ 40 \mathrm{~K}$ p.a. to the total of $£ 1 \mathrm{~m}$ for the five years of the programme. This supports co-ordination ...".

\section{A HUNDRED YEARS AGO}

\section{Influence of Surroundings in Producing Insanity}

In the last number of the Journal of Mental Science Dr Savage discusses this question, and begins by protesting against the acceptance of what is a too widely spread notion-viz., that nearly all insanity is the outcome of direct neurotic inheritance. The influence of heredity is not denied or minimised, but the great importance of environment is insisted upon. To quote the words of the author: "We are what we are in mind and body to a great extent as organic results of our forefathers, but that we are no longer naked savages is some evidence that progress and development in the individual and the race may take place as the result of changing surroundings" There can be no two opinions as to the encouragement to be got from such a view. A too great insistence upon heredity as the determining cause of insanity must land us in a hopeless pessimism as regards treatment, whereas a recognition of the influence of surroundings is the first step towards the construction of a reasonable and efficacious system of therapeutics. The author also cites many examples of hallucinations and delusions which are suggested by surroundings; and whilst all will not be inclined to accept his dictum that disorder of function may lead to disease of tissue, there will be few who will not share his opinion as to the efficacy of restful, pleasant surroundings in the treatment of mental disorder as compared with the virtues of "medicine out of a bottle".

\section{Reference}

Lancet, 31 October 1891, 998.

Researched by Henry Rollin, Emeritus Consultant Psychiatrist, Horton Hospital, Surrey. 